Dicle Üniversitesi Veteriner Fakültesi Dergisi
https://dergipark.org.tr/tr/pub/duvetfd
$\begin{gathered}\text { Araştırma Makalesi/Research Article } \\ \text { Dicle Üniv Vet Fak Derg 2021;14(1):67-72 } \\ \text { DOl: 10.47027/duvetfd.862335 }\end{gathered}$

\title{
Buzağılarda Göbek Bölgesi Lezyonlarının Klinik ve Sağaltım Yönünden Değerlendirilmesi: 100 Olgulu Retrospektif Bir Çalışma
}

\author{
Ibrahim YURDAKUL ${ }^{1, a, \varpi}$, Kadri KULUALP ${ }^{2, b}$, Mustafa YALÇIN ${ }^{1, c}$ \\ ${ }^{1}$ Sivas Cumhuriyet Üniversitesi, Veteriner Fakültesi, Cerrahi Anabilim Dalı, Sivas, TÜRKiYE \\ 2Dokuz Eylül Üniversitesi, Veteriner Fakültesi, Cerrahi Anabilim Dalı, İzmir, TÜRKiYE \\ aORCID: 0000-0002-5696-5069; ' ORCID: 0000-0002-5877-0054; 'ORCID: 0000-0002-5479-1165
}

\begin{tabular}{ccc}
\hline Geliş Tarihi/Received & Kabul Tarihi/Accepted & Yayın Tarihi/Published \\
03.02 .2021 & 11.05 .2021 & 30.06 .2021 \\
\hline
\end{tabular}

Öz

Bu çalışmada; 2017-2020 yılları arası Sivas Cumhuriyet Üniversitesi Veteriner Fakültesi Cerrahi Kliniğine göbek lezyonu şikâyeti ile getirilen buzağıların tanı, uygulanan tedavi şekli ve sonuçları retrospektif olarak değerlendirildi. Çalışmanın materyalini çeşitli şikayetlere bağlı olarak getirilen toplam 350 adet buzağıdan göbek bölgesi lezyonu tespit edilen farklı ırk, yaş ve cinsiyette 100 adet (\%28.57) buzağı oluşturdu. Göbek lezyonlu buzağıların 64'nü (\%64) erkek, 36'sını (\%36) dişiler oluşturdu. Göbek bölgesi lezyonu tespit edilen buzağılar ırklara göre değerlendirildiğinde Simmental ırkı 55 (\%55), Montofon ırkı 38 (\%38), Holstein ırkı 2 (\%2), Şarole ırkı 2 adet (\%2), Yerli ırk 2 (\%2) ve Angus ırkı 1 adet (\%1) olarak tespit edildi. Göbek lezyonlu buzağıların olgulara göre dağılımlarını sırasıyla 35 adet (\%35) omfaloflebitis, 25 adet (\%25) hernia umbilikalis, 17 adet (\%17) omfalitis, 9 adet (\%9) omfaloflebitis+omfaloarteritis, 6 adet (\%6) omfaloarteritis, 4 adet (\%4) göbek apsesi, 2 adet (\%2) urakus fistülü ve 2 adet (\%2) evantratio umbilikalisin oluşturduğu belirlendi. Omfalitis (omfaloflebitis, omfaloarteritis) olgularında göbek kordonu kalınlaşmaları 64 olguda $0.5-3 \mathrm{~cm}, 3$ olguda ise $4 \mathrm{~cm}$ olarak ölçüldü. Fıtık defekt genişliği ortalama $2.8 \mathrm{~cm}$ çapında olan 19 olguya açık herniyorafi, $8.25 \mathrm{~cm}$ çapında olan 6 olguya ise herniyoplasti yapıldı. Sonuç olarak; yeni doğan buzağılarda önemli ekonomik kayıplara neden olan göbek lezyonlarının erken tanı ve erken cerrahi sağaltım yöntemleri ile ekonomik kayıpların önüne geçilebileceği kanısına varılmıştır.

Anahtar Kelimeler: Buzağı, göbek lezyonu, retrospektif değerlendirme

Clinical and Treatment Evaluation of Umbilical Lesions in Calves: A Retrospective Study of 100 Cases

\section{Abstract}

In this study; the diagnosis, treatment method and results of calves brought to Sivas Cumhuriyet University Veterinary Faculty Surgery Clinic with a complaint of umbilical lesion between 2017-2020 were evaluated retrospectively. The material of the study consisted of 100 calves (28.57\%) of different breeds, ages and genders, with umbilical lesions from 350 calves brought to the surgery clinic between 2017 and 2020 due to various complaints. 64 (64\%) of the calves with umbilical lesions were male and $36(36 \%)$ were female. Umbilical lesions are evaluated according to breeds Simmental breed calves 55 (55\%), Brown-Swiss $38(38 \%)$, Holstein 2 (2\%), Charolaise 2 (2\%), Domestic $2(2 \%)$ and Angus $1(1 \%)$. The distribution of umbilical lesions according to the cases was diagnosed as 35 (35\%) omphalophlebitis, 25 (25\%) hernia umbilicalis, $17(17 \%)$ omphalitis, 9 (9\%) omphalophlebitis with omphaloarteritis, $6(6 \%)$ omphaloarteritis, 4 umbilical abscesses (4\%), 2 uracus fistulas (2\%) and 2 evantratio umbilicalis were determined. In omphalitis (omphalophlebitis, omphaloarteritis) cases, umbilical cord thickening was measured as $0.5-3 \mathrm{~cm}$ in 64 cases and $4 \mathrm{~cm}$ in 3 cases. Open herniorrhaphy was performed in 19 cases with an average diameter of $2.8 \mathrm{~cm}$, and hernioplasty in 6 cases with a diameter of $8.25 \mathrm{~cm}$. As a result; it was concluded that the animals can survive for a long time with early diagnosis and early surgical treatment of umbilical lesions that cause significant economic losses in newborn calves.

Key Words: Calves, umbilical lesion, retrospective evaluation

\section{Giriş}

Yeni doğan buzağıların göbek bölgesi lezyonları; sindirim ve solunum sistemi hastalıklarından sonra en sık görülen problemlerdir (1). Bu lezyonlar gerek yüksek tedavi maliyetlerinden gerekse de buzağıların büyüme ve gelişmesini olumsuz yönde etkilemelerinden dolayı ciddi ekonomik kayıplara neden olurlar $(2,3)$. Yeni doğan buzağıların cerrahi hastalıkları içerisinde önemli bir yere sahip olan göbek bölgesi enfeksiyonları ve komplikasyonlarının görülme sıklığının \%1.3- 29.9 arasında değiş̧iği rapor edilmiştir (4).

Yeni doğan buzağılarda doğumu takiben göbek kordonu koptuktan sonra herhangi bir komplikasyon olmaması durumunda ortalama 5 . günde kapanır $(5,6)$. Göbek bölgesi; yeni doğan buzağılarda göbek kordonunun kısa kesilmesi veya kopması, göbek kordonu bakımının yeterince yapılmaması, barınak ortamının hijyenik olmaması, kolostrumun yeterli miktarda alınamaması, pasif antikor geçişi ve kalıtsal 
özellikler gibi bir çok faktöre bağlı olarak patojen mikroorganizmaların yayılması için uygun bir ortam haline gelir. Bu durum göbek bölgesi lezyonlarının oluşmasına predispozisyon yaratır $(2,7,8)$.

Neonatal buzağılarda omfalitis (göbek kordonunun yangısı), omfaloflebitis (v. umbilikalis'in yangısı), omfaloarteritis (a. umbilkalis'in yangısı), urakus fistülü (göbekten işeme), hernia umbilikalis (göbek fıtkı), göbek apsesi, evantratio umbilikalis (açık kalan göbek deliğinden barsakların dışarı çıkması) olguları göbek lezyonları olarak belirtilmektedir $(1,9)$. Göbek lezyonları karın içi ve karın dışı lezyonlar olarak ikiye ayrılır (10). Doğumdan sonraki birkaç gün içinde ekstraumbilikal yayılım gösteren bakteriyel kökenli omfalitis olgularında şekillenen subkutan yangı ve apseler, evantratio umbilikalis karın dışı; intra abdominal yayılım gösteren omfaloflebitis, omfaloarteritis ve urakus fistülü de karın içi lezyonları arasında yer alır (10).

Buzağılarda sık olarak görülen diğer bir göbek lezyonu ise tüm ırklarda görülebilen ve kalıtsal faktörlerle veya omfalitis ile ilişkili olduğu da bildirilen umbilikal fıtıklardır (11). Umbilikal fıtıklar annelerin yeni doğan yavrularını kurulamak için göbek bölgesini sürekli yalaması sonucu da şekillenebildiği bildirilmiştir (12).

Yapılan bu çalışmada, yeni doğan buzağılarda karşılaşılan göbek lezyonlarının çeşitliliği, ırk ve cinsiyete göre dağıІımı ve uygulanan sağaltım yöntemlerinin değerlendirilmesi amaçlandı.

\section{MATERYAL VE METOT}

Çalışmanın materyalini, 2017-2020 yılları arasında Sivas Cumhuriyet Üniversitesi Veteriner Fakültesi Hayvan Hastanesi Cerrahi Kliniğine göbek bölgesi lezyonu şikâyeti ile getirilen yaşları 1 gün ile 5 ay arasında değişen çeşitli ırk ve cinsiyette 100 buzağı oluşturdu. Buzağıların göbek bölgesindeki lezyonları ırk, yaş ve cinsiyete göre değerlendirilerek kaydedildi.

Hasta sahibinden alınan detaylı anamnez doğrultusunda göbek bölgesindeki lezyonlar klinik olarak muayene edildi. Klinik muayenede; göbek bölgesinde kompresibilite ve reponibilite özellik gösteren olgulara göbek fıtkı; göbek kordonunda fluktuan yapı gösterenlere göbek apsesi; göbek kordonunda kalınlaşma ve sıcaklık gösterenlere ise omfalitis teşhisi konuldu. Göbek bölgesindeki akıntının niteliğine göre ise göbekten işeyen buzağılara urakus fistülü tanısı konuldu.

Her olgunun vücut ısıSı, nabız ve solunum yönünden genel muayenesi yapıldı. Özellikle enfeksiyona bağlı olarak vücut ısıları yüksek olan omfalitis ve omfalitis ile komplike artrit olgularında klinik muayene bulgularına göre konservatif sağaltım olarak 1 hafta süre ile parenteral antibiyotik (penicillin $1 \mathrm{ml} / 20 \mathrm{~kg}$, sefalosporin $1 \mathrm{ml} / 40 \mathrm{~kg}$ ) tedavisi uygulandı. Kontrol ve ameliyat için 1 hafta sonra kliniğe getirilen olguların çoğunda iyileşme sağlanırken, iyileşmeyen olgular tekrar muayene edilerek operasyona alındı. Operasyona karar verilen olguların tamamına Xylazine hydrochloride'in (Rompun, Bayer, $0.2 \mathrm{mg} / \mathrm{kg} \mathrm{mg} / \mathrm{ml}$ ) intramusküler enjeksiyonu ile yapılan sedasyonu takiben göbek bölgesinin lidokain $\mathrm{HCl}$ (Adokain, Sanovel, $20 \mathrm{mg} / \mathrm{ml}$ ) ile lokal infiltrasyon anestezisi sağlanarak operasyona alındı.

\section{Operasyon Tekniği}

Omfalitis, omfaloarteritis, omfaloflebitis, urakus fistülü, evantratio umbilicalis, göbek apsesi ve göbek fıtığı tanısı konulan buzağıların göbek çevresine uygun uzunluktaki ensizyonu takiben laparotomi yapıldı. Karın boşluğunda yangılaşan ve kalınlaşma gösteren vena ve/veya arter, kalınlaşma gösterdikleri en uç noktadan ligatür konarak ekstirpe edildi. Urakus fistülü olgularında, idrar kesesine en yakın noktada urakus kanalının ligasyonu sağlandı. Açık kalan göbek deliğinden barsakların dışarı çıktığı evantratio umbilikalis olgularında barsaklar; patolojik lezyon varlığı yönünden muayene edilerek \%0,9'luk serum fizyolojik ile temizlendikten sonra karın boşluğuna yerleştirildi. Göbek apsesi olgularında kapsülünün delinmemesine özen gösterilerek apse ekstirpe edildi. Fıtık olgularında ise laparotomiden sonra fıtık bölgesi yapışmalar ve boğumlanmalar yönünden kontrol edildi. Fıtık deliğinin kolaylıkla kapanabileceği olgularda; deliği çevreleyen kaslara 2-3 numara emilmeyen ipek iplik (Ijpek, Medeks ${ }^{\circledR}$, İstanbul) kullanılarak ve matress tekniği uygulanarak herniyorafi gerçekleştirildi. Fıtık deliğinin herhangi bir dikiş tekniği ile kapatılamayacağı olgulara ise herniyoplasti uygulandı. Herniyoplasti amacıyla sentetik tül mesh fıtık deliği kenarlarına basit ayrı dikiş tekniği ile tutturuldu. Deri altı dokular 23 numara emilebilir poliglactin 910 (Vicryl; Ethicon) ipliği kullanılarak basit sürekli dikiş; deri ise 1 numara ipek iplik ile basit ayrı dikiş teknikleri kullanılarak dikildi.

\section{Postoperatif Bakım}

Postoperatif olarak olgulara parenteral yolla 3 gün süreyle 1 $\mathrm{ml} / 10 \mathrm{~kg}$ dozunda metamizol sodyum (Difaljin, CEVA-DiF) ile 7 gün süreyle $1 \mathrm{ml} / 20 \mathrm{~kg}$ dozunda penisilin+streptomisin (Reptopen S, CEVA-DIF) uygulanması, operasyon bölgesinin lokal antiseptiklerle rutin olarak temizlenmesi, aşırı beslenmeden kaçınılması, mümkünse öğün sayısının artırılarak beslemenin azar azar yapılması ve tam bir iyileşme olana kadar buzağıların hareketlerinin kısıtlanması önerildi. Postoperatif 10-15. günde deri dikişleri alındı ve buzağıların genel durumu değerlendirildi.

\section{BULGULAR}

Sivas Cumhuriyet Üniversitesi Veteriner Fakültesi Cerrahi Kliniğine çeşitli şikâyetlere bağı olarak 2017-2020 yılları arasında toplam 350 adet buzağı getirildi. Bu hastalar içinde göbek bölgesi lezyonu şikâyeti olan ve yaşları 1 gün ile 5 ay arasında değişen toplam 100 adet (\%28.57) buzağı muayene edildi.

Göbek lezyonlu buzağıların 64'ünü (\%64) erkek, 36'sını (\%36) dişi buzağılar oluşturdu. Olguların cinsiyete göre dağılımı Tablo 1'de verilmiştir.

Göbek bölgesi lezyonu tespit edilen buzağılar ırklara göre değerlendirildiğinde Simmental ırkı buzağılar 55 adet (\%55), Montofon ırkı buzağılar 38 adet (\%38), Holstein ırkı buzağılar 2 adet (\%2), Şarole ırkı buzağılar 2 adet (\%2), yerli ırk buzağılar 2 adet (\%2) ve Angus ırkı buzağılar 1 adet (\%1) olarak tespit edildi. Olguların ırka göre dağılımı Tablo 2'de verilmiştir. 
Tablo 1. Olguların göbek lezyonu ve cinsiyet yönünden dağııımı.

\begin{tabular}{|c|c|c|c|c|c|c|}
\hline \multirow[t]{2}{*}{ Olgu } & \multicolumn{2}{|c|}{ Erkek } & \multicolumn{2}{|c|}{ Dişi } & \multirow[t]{2}{*}{ Toplam (n) } & \multirow[t]{2}{*}{ Toplam (\% } \\
\hline & $n$ & $\%$ & $n$ & $\%$ & & \\
\hline Omfaloflebitis & 26 & $\% 74.28$ & 9 & $\% 25.72$ & 35 & $\% 35$ \\
\hline H. Umbilikalis & 14 & $\% 56$ & 11 & $\% 44$ & 25 & $\% 25$ \\
\hline Omfalitis & 10 & $\% 58.82$ & 7 & $\% 41.18$ & 17 & $\% 17$ \\
\hline \multicolumn{7}{|l|}{ Omfaloflebitis } \\
\hline$\stackrel{+}{\text { Omfaloarteritis }}$ & 4 & $\% 44.44$ & 5 & $\% 66.66$ & 9 & $\% 9$ \\
\hline Omfaloarteritis & 4 & $\% 66.66$ & 2 & $\% 44.44$ & 6 & $\% 6$ \\
\hline Göbek Apsesi & 2 & $\% 50$ & 2 & $\% 50$ & 4 & $\% 4$ \\
\hline Urakus Fistülü & 2 & $\% 100$ & - & - & 2 & $\% 2$ \\
\hline Evantratio & 2 & $\% 100$ & - & - & 2 & $\% 2$ \\
\hline
\end{tabular}

Tablo 2. Olguların göbek lezyonu ve karşılaşılan ırklar yönünden dağılımı.

\begin{tabular}{|c|c|c|c|c|c|c|c|c|}
\hline \multirow{2}{*}{ Olgu } & \multirow{2}{*}{ Simmental } & \multirow{2}{*}{ Montofon } & \multirow{2}{*}{ Holstein } & \multirow{2}{*}{ Şarole } & \multirow{2}{*}{ Angus } & \multirow{2}{*}{ Yerli } & \multicolumn{2}{|c|}{ Toplam } \\
\hline & & & & & & & $\mathrm{n}$ & $\%$ \\
\hline Omfaloflebitis & 17 & 12 & 1 & 1 & - & - & 31 & 31 \\
\hline H. Umbilikalis & 15 & 9 & - & 1 & & & 25 & 25 \\
\hline Omfalitis & 10 & 8 & - & - & - & - & 18 & 18 \\
\hline \multicolumn{9}{|l|}{ Omfaloflebitis } \\
\hline+ & 6 & 4 & - & - & 1 & - & 11 & 11 \\
\hline \multicolumn{9}{|l|}{ Omfaloarteritis } \\
\hline Omfaloarteritis & 3 & 3 & - & - & - & 1 & 7 & 7 \\
\hline Göbek apsesi & 3 & & 1 & & & & 4 & 4 \\
\hline Urakus fistülü & 1 & & & & & 1 & 2 & 2 \\
\hline Evantratio & - & 2 & & & & & 2 & 2 \\
\hline Toplam (n) & 55 & 38 & 2 & 2 & 1 & 2 & 100 & \\
\hline Toplam (\%) & $\% 55$ & $\% 38$ & $\% 2$ & $\% 2$ & $\% 1$ & $\% 2$ & & 100 \\
\hline
\end{tabular}

Göbek lezyonlu buzağıların 35'i (\%35) omfaloflebitis, $25^{\prime} \mathrm{i}(\% 25)$ hernia umbilikalis, 17'si (\%17) omfalitis, 9'u (\%9) omfaloflebitis+omfaloarteritis, 6'sı (\%6) omfaloarteritis, 4'ü (\%4) göbek apsesi, 2'si (\%2) urakus fistülü ve 2'si (\%2) evantratio umbilikalis olarak teşhis edildi. Olguların yerleştiği bölgeye göre dağılımı Tablo 2'de verilmiştir.

Omfalitis (omfaloflebitis, omfaloarteritis) olgularında göbek kordonu kalınlaşmaları 64 olguda $0.5-3 \mathrm{~cm}, 3$ olguda ise $4 \mathrm{~cm}$ olarak ölçüldü (Şekil 1). Kliniğe topallık şikâyeti ile getirilen toplam 41 adet buzağıda eklem bölgesi lokal ısı artışı, şişkinlik ve fleksiyonda duyarlılık yönünden muayene edildi. Radyografik inceleme amacıyla ilgili eklemin mediolateral (ML) ve anteroposterior (AP) pozisyonlarında radyografileri alındı. illgili eklem bölgesi kıllarının tıraşı sonrası longitudinal ve transversal yönlerden eklemin ultrasonografik muayenesi yapılarak klinik, radyografik ve ultrasonografik bulgular doğrultusunda artrit tanısı konuldu. Artrit tanısı konulan 29 adet monoartrit ve 12 adet poliartrit olmak üzere toplam 41 artritli buzağının göbek bölgesi muhtemel omfalitis yönüyle muayene edildi. Göbek bölgesi muayene edildiğinde göbek kordonlarının kalınlaşmış olduğu ve artrite neden olan asıl hastalığın omfalitis (omfaloflebitis, omfaloarteritis) olduğu tespit edildi. Poliartrit semptomu gösteren 5 olguda septisemi belirlendi.



Şekil 1. Omfaloflebitis ve omfaloarteritis olgusu. V. umbilikalis (siyah ok), A. umbilikalis (mavi ok), Urachus (sarı ok)

Hernia umbilikalis; göbek lezyonlu toplam 100 hasta buzağının 25'inde (\%25) belirlendi. Göbek fıtığı olgularının $14^{\prime}$ ünün erkek (\%56), 11'inin dişi (\%44); 15'inin (\%60) Simmental, 9'unun (\%36) Montofon, 1'inin (\%4) ise Şarole 
olduğu tespit edildi. Bu olguların 19'unda fıtık defektinin ortalama çapı $2.8 \mathrm{~cm}, 6$ olguda ise $8.25 \mathrm{~cm}$ ölçüldü. Fıtık defekt çapı $8.25 \mathrm{~cm}$ olan 6 olguya herniyoplasti yapıldı (Şekil 2). Bu amaçla sentetik tül mesh, fıtık defektinin kenarlarına basit ayrı dikiş tekniği ile tutturuldu. Herniyoplasti yapılan olgular Tablo 3'te verilmiştir.

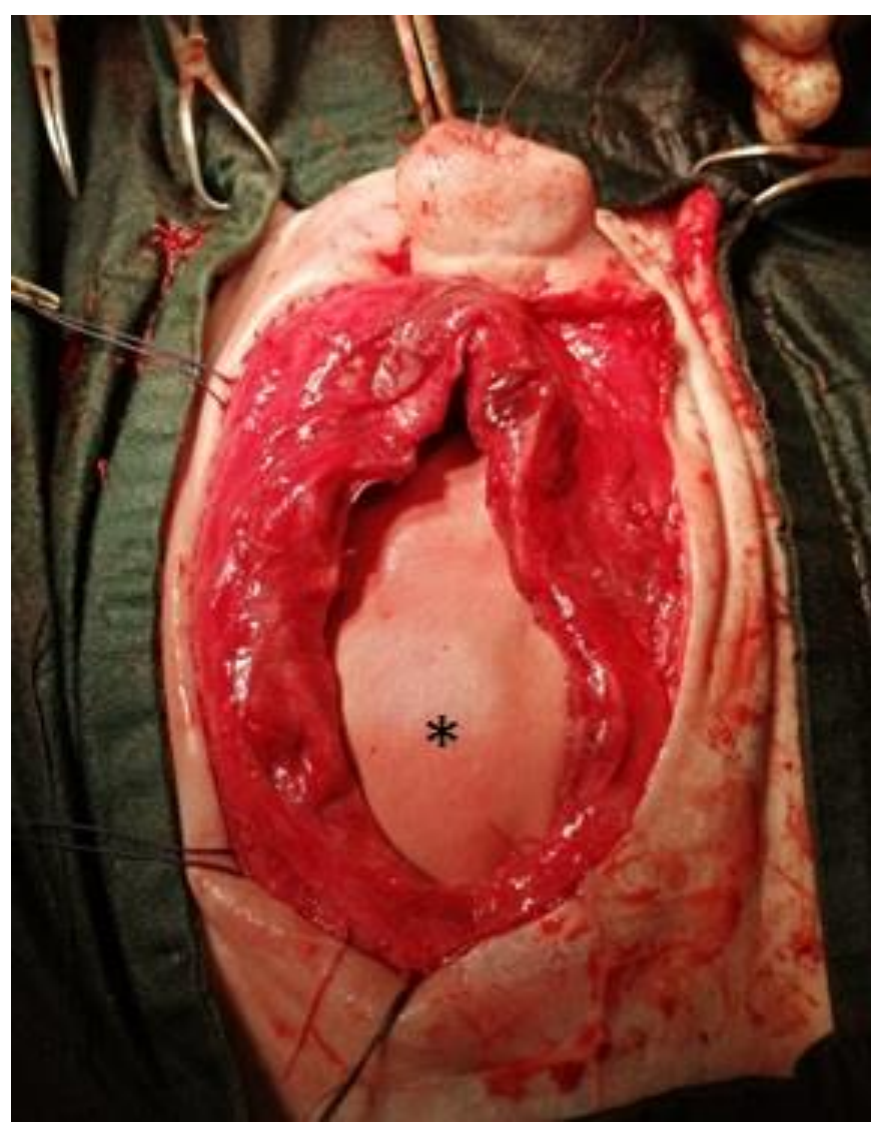

Şekil 2. Herniyoplasti yönteminde fıtık defektinin sentetik tül mesh $(*)$ ile kapatılması

Tablo 3. Herniyoplasti yapılan olgulara ait bilgiler

\begin{tabular}{lrcrc}
\hline Olgu & $\begin{array}{r}\text { Hayvanın } \\
\text { Cinsi, Yaşı, }\end{array}$ & Hayvanın Irkı & $\begin{array}{r}\text { Fıtık } \\
\text { Defekt } \\
\text { Ebat } \\
\text { (cm) }\end{array}$ & Sonuç \\
\hline $\begin{array}{l}\text { Hernia } \\
\text { Umbilikalis }\end{array}$ & Dişi, 6 Ay & Montofon & $13 \times 11$ & Ödem \\
\hline $\begin{array}{l}\text { Hernia } \\
\text { Umbilikalis }\end{array}$ & Dişi, 4 Ay & Montofon & $8 \times 10$ & Normal \\
\hline $\begin{array}{l}\text { Hernia } \\
\text { Umbilikalis }\end{array}$ & Dişi, 2 Ay & Simmental & $7 \times 5$ & Normal \\
\hline $\begin{array}{l}\text { Hernia } \\
\text { Umbilikalis }\end{array}$ & Erkek, 1.5 Ay & Şarole & $6 \times 6$ & Normal \\
\hline $\begin{array}{l}\text { Hernia } \\
\text { Umbilikalis }\end{array}$ & Erkek, 2 Ay & Simmental & $12 \times 8$ & Ödem \\
\hline $\begin{array}{l}\text { Hernia } \\
\text { Umbilikalis }\end{array}$ & Erkek, 1.5 Ay & Simmental & $7 \times 6$ & Normal \\
\hline
\end{tabular}

Herniyorafi gerçekleştirilen olguların 15'inde fıtıklaşan organın omentum, 4 olguda ise omentum ile birlikte barsaklar olduğu belirlendi. Omentum ile barsakların beraber fıtıklaştığı olgularda fıtık deliği çevresinde yapışmalar görülmesine rağmen boğumlanmanın olmadığı anlaşıldı. İç fıtık kesesine yapışan omentum ve barsaklar, parmaklar yardımı ile küt bir şekilde diseke edilerek yapışmalardan kaynaklanabilecek herhangi bir lezyon yönünden muayene edildi. Lezyon olmadığı anlaşıldıktan sonra organların zarar görmeden karın boşluğuna reddi sağlandı.

Herniyoplasti uygulanan 2 olgunun operasyon bölgesinde postoperatif 4 . günde ödem şekillendiği bilgisi alındı. Ancak olgular postoperatif 10 . günde dikişlerinin alınması için kliniğe getirildiklerinde bu ödemin önemli ölçüde azaldığı görüldü. Herhangi bir komplikasyona yol açmamak amacıyla deri dikişleri 15. günde alındı.

Urakus fistülü olgularının birinde tam göbekten işeme mevcut iken diğer olguda ise damla damla göbekten işeme ile beraber bir miktar idrarın urakus kanalından sızıntı yaparak göbek bölgesinde deri altında toplandığı tespit edildi (Şekil 3a). Her iki olguda urakus kanalının idrar kesesine en yakın noktasından ligasyonu sağlandı (Şekil 3b). Deri altında idrar toplanan olguda laparotomiyi takiben idrarın bulaştığı deri altı doku kısımları temizlenerek ve abdominal boşluğa idrar sızıntısının olmadığı kontrol edilerek operasyon tamamlandı.

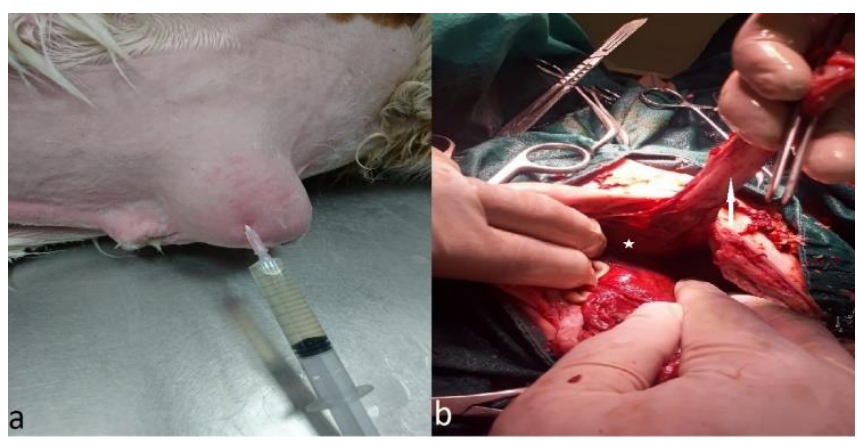

Şekil 3. (a): Urakus fistülünde deri altında idrar, (b): Urachus (beyaz ok) ve fistülün sonlandığı idrar kesesi (沉)

\section{TARTIŞMA VE SONUÇ}

Göbek bölgesi lezyonları ve bunlara bağlı gelişen enfeksiyonlar; yeni doğan buzağıların en sık karşılaşılan problemleri arasındadır (13). Etkili bir şekilde tedavi edilmeyen omfalitis, omfaloflebitis, omfaloarteritis, urakus fistülü, göbek apsesi ve hernia umbilikalis sonucu gelişen enfeksiyonlar; hematojen yolla eklemlere, akciğerlere, böbreklere ve diğer organlara taşınarak ciddi komplikasyonlara ve hatta ölüm oranının artmasına neden olabilirler $(14,15)$. Mevcut çalışmada göbek bölgesi lezyonlarının görülme sıklığı \%28.57 olarak tespit edilmiştir. Bu sonuç problemin sık görüldüğünü rapor eden araştırmacıların (13) görüşünü destekler niteliktedir.

Yeni doğan buzağılarda göbek bölgesi lezyonlarının erkeklerde dişilere oranla daha fazla görüldüğü çeşitli araştırmacılar tarafından bildirilmektedir $(12,16,17)$. Sağlıyan ve ark. (16) yaptıkları çalışmada 178 olgunun 94'ünün erkek (\%52.81), 84'ünün dişi (\%47.19); Belge ve ark. (12) 112 olgunun 66'sının erkek (\%59), 46'sının dişi (\%41), Kılıç ve ark. (17) 95 olgunun 54'ünün erkek (\%57), 41'inin ise dişi (\%43) olduğunu bildirmişlerdir. Bu çalışmaların sonuçlarına benzer şekilde göbek lezyonu tespit edilen 100 olgumuzun 64'ünün erkek (\%64), 36'sının ise dişi (\%36) olduğu kaydedilmiştir. Lezyonların dişilere göre erkeklerde biraz daha fazla görülmesi, Belge ve ark. (12) da belirttiği üzere uretranın erkek hayvanlarda göbeğe çok yakın bölgeden dışarı açılmasından ve 
doğumdan sonra göbek kordonunun idrar ile temasta bulunmasından kaynaklanabilir.

Eldeki veriler ırk faktörüne göre değerlendirildiğinde göbek bölgesi lezyonlarının 55'i Simmental (\%55), 38'i Montofon (\%38), 2'si Holstein (\%2), 2'si Şarole (\%2), 2'si yerli (\%2), 1'i ise Angus ırkı (\%1) buzağılardan oluşmaktaydı. Buradan da anlaşılacağı üzere kliniğimize göbek bölgesi lezyonu şikayetiyle getirilen buzağıların \%55'inin Simmental ırkına ait olduğu kaydedilmiştir. Bu sayıların hastalığın hangi ırkta daha fazla görüldüğünü ortaya koymaktan ziyade bölgemizde yetiştirilen ırkların dağılımını göstermesi açısından daha anlamlı olduğunu düşünmekteyiz.

Bazı araştırmacılar $(18,19)$ omfaloflebitis ve urakus enfeksiyonlarının göbek bölgesi lezyonları içinde en fazla; omfaloarteritis olgularının ise en az karşılaşılan olgular olduğunu belirtmektedirler. Kılıç ve ark. (17), yaptıkları çalışmada omfaloflebitis olgularını \%25.2, urakus enfeksiyonlarını ise \%28.4 oranında en sık görülen iki olgu olarak; Moscuzza ve ark. (19) omfaloflebitis olgularını \%53 ile en çok, omfaloarteritis olgularını ise \%17.4 ile en az görülen olgu olarak rapor etmişlerdir. Mevcut çalışmamızda en sık görülen göbek bölgesi lezyonları sırasıyla omfaloflebitis (n: 35 ) \%35, hernia umbilikalis ( $n$ : 25 ) \%25 ve omfalitis ( $n: 17) \% 17$; en az görülen olgular ise omfaloarteritis (n: 6) \%6, göbek apsesi (n: 4) \%4, urakus fistülü (n: 2) \%2, evantratio umbilikalis (n: 2) \%2 olarak tespit edilmiştir. Bu veriler yukarıdaki araştırmacıların $(17,19)$ sonuçlarını destekler nitelikte olup; omfaloflebitis ve urakus enfeksiyonu gibi hastalıkların daha çok görülme nedeni olarak genellikle yaşamın ilk günlerinde kötü hijyen, göbek bakımının yapılamaması veya eksik yapılması, buzağıların doğumdan hemen sonra alması gereken kolostrumu yeterince almaması neticesinde pasif bağışıklığın aktarılamaması ile yakından ilişkili olduğunu göstermektedir.

Araştırmacılar $(3,5,20)$ göbek kordonundaki enfeksiyon etkenlerinin portal ven aracılığı ile eklem gibi daha uzak yapılara yayılarak artrit başta olmak üzere çeşitli sekonder hastalıklar oluşturduğunu ve omfaloflebitis vakalarının \%50 sinden fazlasında en sık gözlenen komplikasyonun septik artritis olduğunu bildirmişlerdir $(5,18)$. Sunulan bu çalışmada topallık problemi ile getirilen buzağıların klinik muayeneleri neticesinde göbek bölgesi lezyonu gösteren (omfalitis, omfaloflebitis, omfaloarteritis) 64 olguda 29 adet (\%45.31) monoartrit ve 12 adet (\%18.75) poliartrit olmak üzere toplam 41 artritli (\% 64.06) buzağı tespit edildi. Mevcut çalışmada göbek lezyonu gösteren 100 olgu (omfalitis, omfaloflebitis, omfaloarteritis, göbek fıtkı, göbek apsesi, urakus fistülü, evantratio umbilicalis) içerisinde artrit olguları \%41 gibi yüksek bir oran olarak belirlendi.

Hernia umbilikalis, daha çok 1-3 aylık buzağılarda görülen $(21,22)$; göbek bölgesinde derinin altında değişik büyüklükte, esnek kıvamda, ağrılı ya da ağrısız seyreden, red edilebilen veya edilemeyen bir şişkinlikle karakterizedir (5). Neonatal buzağılarda hernia umbilikalis; kongenital ya da göbek bölgesi enfeksiyonları sonucu göbek çevresindeki kasların zayıflamasına ve diğer yandan intra abdominal basıncın artışına bağlı olarak gelişmektedir (23). Çalışmamızda göbek bölgesi lezyonu tespit edilen toplam 100 buzağının 25'inde (\%25) göbek fıtığı ile karşılaşılmıştır. Kongenital umbilikal fıtığın tüm buzağı ırklarında yaygın görüldüğü belirtilse de en çok (\%4-\%15) Holstein Friesian ırkı buzağılarda görüldüğü rapor edilmiştir $(21,24)$. Sağlıyan ve ark. (16), Elazığ yöresinde yaptıkları çalışmada 54 göbek fıtığı olgusunun 21'ini Simmental, 15'ini Montofon, 13'ünü Holstein; Kılıç ve ark. (17) ise Aydın yöresinde yaptıkları çalışmada 22 göbek fıtığı olgusunun 15 'ini Holstein Friesian ırkı buzağılar oluşturduğunu bildirmişlerdir. Sivas yöresinde yaptığımız bu çalışmada, göbek fıtığı olgularının ırklara göre dağılımına bakıldığında 25 olgudan 15'inin Simmental, 9'unun Montofon, 1'inin ise Şarole ırkı buzağılardan oluştuğu görüldü. Eldeki verilerden hareketle göbek fıtığı olguları ırklara göre değerlendirildiğinde, dağılımın yetiştirilen hâkim ırklardan kaynaklı bölgelere göre farklılıklar göstereceği düşünülmektedir.

Yeni doğan buzağılarda göbek açıklığı doğumdan birkaç gün sonra kendiliğinden kapanmaktadır. Ancak omfalitis veya göbek apsesi gibi kongenital veya edinsel faktörler göbek açıklığının kapanmasını engelleyerek göbek fıtığına sebep olmaktadır (25). Fıtık çapının 1-3 cm den küçük olduğu hernia umbilikalis olgularında bu açıklığın kendiliğinden kapanacağı (24), fıtık çapının 4-5 cm den küçük olduğu olgularda göbek bölgesinin elastik bir bandajla sarılması sonucu göbek açıklığının 2-3 ay içerisinde kapanacağı $(23,24)$, fıtık çapı $6 \mathrm{~cm}$ den büyük olan olgularda ise göbek açıklığının kapanmasının cerrahi müdahale ile sağlanacağı belirtilmekte$\operatorname{dir}(24)$.

Sunulan bu çalışmada toplam 25 göbek fıtığı olgusunun 19'unun fıtık defekt çapı ortalama $2.8 \mathrm{~cm}, 6$ olgunun ise ortalama $8.25 \mathrm{~cm}$ olarak ölçülmüştür. Fıtık çapı küçük olanlarda defektin kendiliğinden kapanacağı bildirilse de; olguların içinde bulundukları hijyenik ortam ile buzağıların hızlı bir şekilde büyümesine paralel olarak fıtık defektinin genişleyebileceği de göz önüne alınarak tüm hernia umbilikalis olgularında operatif işlem gerçekleştirilmiştir. Fıtık defekt çapı ortalama $2.8 \mathrm{~cm}$ olan 19 olguya açık herniyorafi, $8.25 \mathrm{~cm}$ çapında olan 6 olguya ise herniyoplasti yapılmıştır. Herniyoplasti de kullanılacak olan greftlerin gevşek veya aşırı gergin olmamasının, karın iç basıncını karşılayacak derecede sağlam olmasının ve operasyondan sonra herhangi bir komplikasyon oluşturmamasının iyileşmeye önemli katkılar sağlayacağı belirtilmektedir. Koç ve ark. (26) greft olarak sentetik tül mesh kullandıkları 23 olgunun üçünde postoperatif komplikasyon yönünden sadece ödemin şekillendiğini ve bu ödemin de bir hafta sonra kaybolduğunu bildirmişlerdir. Hem kolay temin edilebilir hem de ekonomik olması nedeniyle herniyoplasti uyguladığımız 6 olguda da greft olarak sentetik tül mesh kullanıldı. Postoperatif olarak bu olguların 2'sinde hafif bir ödem kaydedildi.

Sonuç olarak; yeni doğan buzağılarda hem gelişme geriliği hem de tedavi masrafları nedeniyle önemli ekonomik kayıplara neden olan göbek bölgesi lezyonlarının erken teşhis edilerek doğru cerrahi tekniklerin kullanılması ile kolaylıkla iyileşeceği ve bu sayede hayvanların yaşam kalitelerinin ve sürelerinin artacağı öngörülmektedir. Göbek bölgesi lezyonlarının önlenmesinde yetiştiricilerin bilinçlendirilmesi de ayrıca önem arz etmektedir. 


\section{KAYNAKLAR}

1. Guerri G, Vignoli M, Palombi C, Monaci M, Petrizzi L. (2020). UItrasonographic Evaluation of Umbilical Structures in Holstein Calves: A Comparison Between Healthy Calves and Calves Affected by Umbilical Disorders. J Dairy Sci.103: 1-13.

2. Tan E, Yayla S. (2018). Buzağılarda Göbek Fıtıklarının Onarımında Greft Kullanımının Postoperatif Ağrı Üzerine Etkinliğinin Değerlendirilmesi. Turkiye Klinikleri J Vet Sci. 9: 8-16.

3. Bozukluhan K, Merhan O, Öğün M, Cihan M, Gökçe G. (2016). Omfalitisli Buzağılarda Bazı Oksidatif Stres Parametre Düzeylerinin Belirlenmesi. FÜ Sağ Bil Vet Derg. 30: 79-81.

4. Wieland M, Mann S, Guard CL, Nydam DV. (2016). The Influence of 3 Different Navel Dips on Calf Health, Growth Performance, and Umbilical Infection Assessed by Clinical and Ultrasonographic Examination. J Dairy Sci. 100: 1-12.

5. Alkan F, Koç Y, Sulu K. (2019). Yeni Doğan Buzağılarda Göbek Lezyonları: Yeni Doğan Buzağılarda Enfeksiyöz Seyirli Göbek Lezyonları ve Sağaltım Seçenekleri. Baran V, editör. Ruminantlarda Neonatal Cerrahi. 1. Baskı. Ankara: Türkiye Klinikleri; $p$. 40-44.

6. Hides SJ, Hannah MC. (2005). Drying Times of Umbilical Cords of Dairy Calves. Aust Vet J. 83: 371-373.

7. Mee J. F. (2008). Newborn Dairy Calf Management. Vet Clin North Am Food Anim Pract. 24: 1-17.

8. Salcı ESÖ, Salcı H. (2012). Anatomo-Physiological Involution of Umbilical Cord, Umbilical Hygiene and Etiopathogenesis of the Umbilical Lesions in Calves. Res Opin Anim Vet Sci. 2: 587-590.

9. Ganga NS, Ananda KJ, Kavitha RB, Kotres AM, Shambulingappa BE, Patel SR. (2011). Navel III in New Born Calves and Its Successful Treatment. Vet World. 4: 326-327.

10. Görgül S. (2012). Özel Cerrahi. Medipres Matbaacılık Yayıncılık Ltd Şti. Malatya, Sf 232-238.

11. Farman RH, Al-Husseiny SH, Abd Al-Ameer AN. (2018). Surgical Treatment of Hernia in Cattle: A Review QJVMS. Vol. 17 No. (2) 6th (1st international) Scientific Conference 27-28 Sep.

12. Belge A, Bakır B, Atasoy N, Alkan i. (1996). Buzağılarda Göbek Lezyonları. YYÜ Vet Fak Derg. 7: 14-17.

13. Yurdakul i. (2016). Kuzu Ve Oğlaklarda Göbek Kordonu Enfeksiyonuna Bağı Komplikasyonlar. Cumhuriyet Üniv Sağ Bil Enst Derg. 1: 39-45.

14. Hosie BD. (2007). Prolapse and Hernia. In: Aitken ID (Ed). Diseases of Sheep. $4^{\text {th }}$ ed. Oxford UK: Blackwell Publishing. p. 98.

15. Wieland M, Mann S, Guard CL, Nydam DV. (2016). The Influence of 3 Different Navel Dips on Calf Health, Growth Performance, and Umbilical Infection Assessed by Clinical and Ultrasonographic Examination. J Dairy Sci. 100: 513-524.
16. Sağlıyan A, Han MC, Günay C. (2016). Buzağılarda Göbek Bölgesi Lezyonlarının Klinik, Radyografik ve Ultrasonografik Olarak Değerlendirilmesi. F Ü Sağ Bil Vet Derg. 30: 123 - 129.

17. Kılıç N, Derincegöz OÖ, Yaygıngül R. (2005). Surgical Correction of Umbilical Disease in Calves: A Retrospective Study of 95 Cases. YYÜ Vet Fak Derg. 16: 35-38.

18. Marchionatti E, Nichols S, Babkine M, et al. (2016). Surgical Management of Omphalophlebitis and Long Term Outcome in Calves: 39 Cases (2008-2013). Vet Surg. 45: 194-200.

19. Moscuzza C, Milicich H, Álvarez G, Gutierrez B, Nahum M. (2014). Calving Assistance Influences the Occurrence of Umbilical Cord Pathologies Treated Surgically in Calves. Turk J Vet Anim Sci. 38: 405-408.

20. Constant C, Nichols S, Desrochers A, et al. (2018). Clinical Findings and Diagnostic Test Results for Calves with Septic Arthritis: 64 Cases (2009-2014). JAVMA. 252: 995-1005.

21. Nath SK, Sen AB, Rahman MM, Das S, Ersam R, Alam MR. (2016). Umbilical Hernia in Calves in Sylhet Region, Bangladesh. Int. J Adv Multidiscip Res. 3: 19-25.

22. Rahman MM, Sultana S, Ali MZ, Hassan MZ. (2017). Prevalence of Umbilical Hernia of Calves and Its Risk Factors at Tangail Sadar of Bangladesh. Asian Australas J Biosci Biotechnol. 2: 154158.

23. Doijode V. (2019). Umbilical Hernia in Ruminant calves: A Review. Pharma Innovation. 8: 164-167.

24. Dehury KC, Sathapathy S, Joshi SK, Mishra CB, Ali I, Behera HK. (2017). Surgical Management of Umbilical Hernia in Crossbred Holstein-Friesian Calf. GJBB. 6: 693-696.

25. Fesseha H. (2020). Umbilical Hernia in Cross Holstein Friesian Calf and Its Surgical Management: A Case Report. Vet Med Open J. 5: 39-42.

26. Koç. Y, Çiftçi MK, İzci C, Türkütanıt SS, Arıcan M. (1992). Geniş Defektli Fıtıkların Kapatılmasında Sentetik Tül Kullanımı Üzerine Klinik ve Histopatolojik Araştırmalar. SÜ Vet Fak Derg. 8: 37-43.

\section{Sorumlu Yazar:}

ibrahim YURDAKUL

Sivas Cumhuriyet Üniversitesi, Veteriner Fakültesi, Cerrahi Anabilim Dalı, Sivas, TÜRKIYE

E-posta: ibrahimyurdakul5858@hotmail.com 